일반논문 $-08-13-4-05$

\author{
디지털 FWS간 허용 간섭 기준

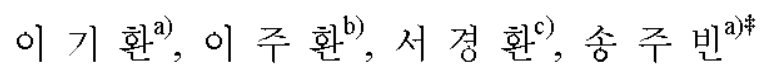

\title{
Allowable Interference Criteria Between Digital FWSs
}

\author{
Ki Hwan Lee ${ }^{a}$, Joo Hwan Lee ${ }^{\text {b) }}$, Kyoung-Whoan Suh ${ }^{\text {c) }}$, and Ju Bin Song ${ }^{\text {a) }}$
}

요 약

각종 디지털 신규 서비스의 도입으로 인해 발생하는 기존 FWS(Fixed Wireless System) 대역 점유 시스템과 신규 디지털 FWS 간에 발생하는 간섭을 효율적으로 다루기 위해 허용 간섭 기준의 산출이 요구된다. 본 논문에서는 디지털 FWS의 허용 간섭 기준 을 산출하기 위한 방법론을 제안하였다. 디지털 $\mathrm{FWS}$ 의 간섭 유형을 정의하였고, 전송 채널의 특성을 분석하였다. 제안한 방법을 적용하여 다양한 $\mathrm{M}$ 진 $\mathrm{QAM}$ 변조 방식에 따른 허용 간섭 기준을 분석하였다.

\begin{abstract}
The method to determine allowable interference criteria is required due to new digital FWSs(Fixed Wireless Systems) adding to allowable frequency bands, besides current FWSs and digital FWSs. In this paper, we suggested a method to define allowable interference between digital FWSs. Types of interference for FWS were defined and channel characteristics were analyzed. Allowable interference criteria were analyzed using the suggested method for M-ary QAM modulations, which is typical modulation technique of digital FWS.
\end{abstract}

Key words : Fixed Wireless System, Digital Fixed Wireless System, Allowable Interference Criteria, M-ary QAM Modulation

\section{I. 서 론}

최근 아날로그 방식으로 운용되던 TV 전송 방식이 디지 털 전송 방식으로 전환되고 있다. 또한 위성 $\mathrm{DMB}$ 등 각종 신규 디지털 전송 방식이 도입됨에 따라 관련 서비스의 원 활한 제공을 위한 주파수 대역에 대한 요구가 발생하고 있

a) 경희대학교 전자전파공학과

Dept. of Electronics and Radio Engineering, Kyung Hee Univ.

b) 한국전자통신연구원 스펙트럼공학연구텀

Spectrum Engineering Research Team, ETRI

c) 강남대학교 전자공학과

Dept. of Electronic Eng., Kangnam Univ.

\# 교신저자 : 송주빈(jsong@khu.ac.kr)

※본 연구는 한국전자통신연구원(ETRI)의 지원에 의해 수행되었음.
다 ${ }^{[1]}$. 이에 따라 기존의 광대역 무선 업무와 디지털 고정 통 신망(FWS)간의 간섭으로 인한 많은 성능 오류가 예상된다. 디지털 FWS의 효율적인 주퐈수 사용을 위한 시스템간의 공 유 조건에 대한 연구의 필요성이 제기되고 있다. 디지털 FWS의 주파수 공유는 인접 시스템간의 간섭에 많은 영향을 받기 때문에 인접 시스템의 간섭에 따른 성능 열화량 예측 이 반드시 선행 되어야 한다. 특히 디지털 전송 방식별 간섭 에 의한 성능 열화량 예측 연구가 요구된다 ${ }^{[2]}$. 주퐈수 자원 이 날로 부족해지고 있는 현실을 감안할 때 신규 디지털 통 신 및 방송 서비스에 대한 디지털 FWS 주파수 자원의 이용 률 극대화 및 공유화를 위해 디지털 FWS의 채널 특성, 간섭 모델, 디지털 변조방식에 따른 성능 지수 등의 퐈라미터를 
고려한 최적의 간섭 기준 산정에 대한 연구가 필요하다.

일반적으로 무선 통신망의 간섭에 대한 분석은 해당 무선 망에서 최대 허용 간섭량을 나타내는 보호비(PR : Protection Ratio)가 기준이 된다 ${ }^{[3][4][5]}$. 보호비는 돟일 또는 타 무선 통신 시스템간의 망 설계에 적용되는 중요한 변수이다. 실제 무선망 설계에서는 해당 수신기에 유입되는 원하는 신호(C) 와 원하지 않는 간섭(I)의 비를 계산하여 기 도출한 보호비와 비교하게 된다. 이 때, 보호비가 C/I(Carrier to Inter- ference) 보다 크면 해당 무선망 설계가 적절하게 되었다고 판단한다. 보호비는 특정 비트 오율에 주어지는 수신기 감도, 다중 간섭 허용, 페이드 마진의 함수로 표현되며, 인접 채널 간섭의 경 우 통합 필터 변별도(NFD : Net Filter Dis- crimination)가 추가된다. 최근까지 유럽통신표준연구소(ETSI), 국제통신연 합(ITU), 영국 전퐈청(RA) 및 호주의 통신청(ACA)에서는 고 정무선중계 시스템에서의 보호비를 구하기 위한 연구를 진행 하였다 ${ }^{[4][5][6][7][8]}$. 하지만 보호비는 거리, 주파수, 지형, 기후적 특성, 안테나 높이 및 가용율을 포함한 페이드 마진 등 관련 변수의 복잡성으로 인해 산출 과정이 매우 복잡하다. 또한, 변 조 방식의 함수인 수신기 감도를 보호비 산출 과정에서는 일정 한 값으로 고정하여 보호비를 결정함으로써 실제 변조 방식에 따라 보호비의 차이가 존재한다.

본 논문에서는 디지털 FWS의 간섭 기준을 산정하기 위해 계산 및 적용이 쉽고 변조 방식의 변화를 반영할 수 있는 알고리즘을 제안하였다. 특정 비트 오율(BER : Bit Error Rate)을 만족시키기 위한 기준 $\mathrm{C} / \mathrm{N}$ 과 간섭시의 $\mathrm{C} / \mathrm{I}$ 값을 이 용하였고, 이를 $\mathrm{M}$ 진 $\mathrm{QAM}$ 에 적용함으로써 변조 방식에 따 라 시스템 간섭 기준을 산정하였다.

본 논문은 다음과 같이 구성되었다. ㅍㅈ장에서는 FWS 통신 망의 채널 환경 및 허용 간섭 기준 도출 방법론이 제시 되었 으며, III장에서는 이 방법에 따른 시뮬레이션을 통한 결과 를 산출 하였고, 마지막으로 IV장에서 결론을 기술하였다.

\section{FWS 통신망의 특성 및 간섭기준}

\section{FWS 통신망의 채널환경}

제한된 주파수 자원의 효율적 사용 측면에서 간섭에 대
한 연구는 매우 중요한 의미를 지닌다. 간섭은 통신 시스템 의 돟일 주파수 채널 및 인접 주파수 채널에 원하지 않는 신호 전력의 수신으로 정의된다. 이는 복조시 자신의 데이터 복구를 불가능하게 하거나 영향을 준다. FWS의 간섭원은 다음과 같이 정의 될 수 있다 ${ }^{[9]}$.

- 동일 밴드 상에서 동작하는 FWS로부터의 간섭

- 주사용자의 주퐈수를 공유하는 다른 전파 시스템으로 부터의 간섭

- 비 주사용자의 주파수를 공유하는 다른 전파시스템으 로부터의 간섭

- 공유하지 않는 밴드 내에서 에너지확산과 같은 영향으 로 인한 간섭

FWS 망에서는 국소(site)간의 기하학적 배치, 시스템 제

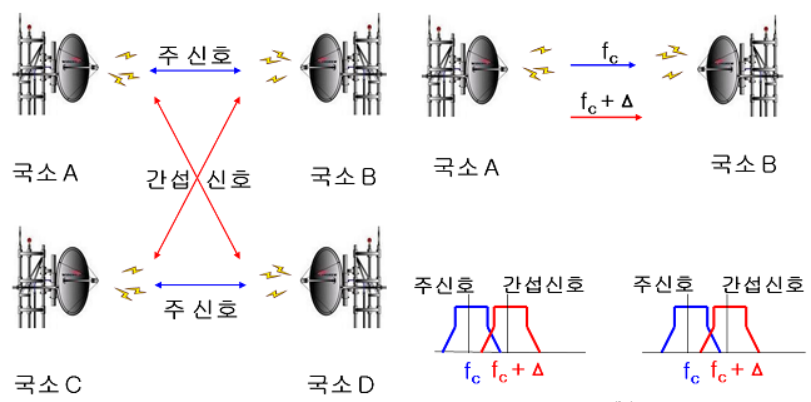

(a) (b)

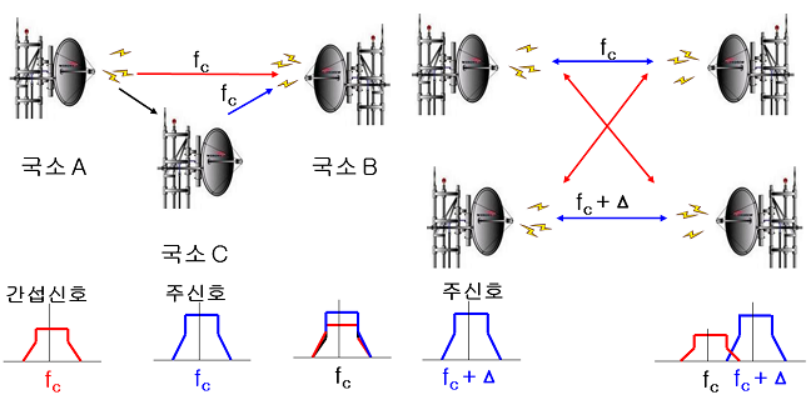

(c)

(d)

그림 1. 간섭 유형 모델 (a) 전형적인 간섭 유형 모델 (b) 동일국소, 인접 주파수 채널 간섭 모델 (c) 다른 경로, 동일 주파수 채널 간섭 모델 (d) 다른 경로, 인접 주파수 채널 간섭 모델

Fig. 1. Interference model (a) Typical interference model (b) Interference model for same site and adjacent frequency channel (c) Interference model for different site and same frequency channel (d) Interference model for different site and adjacent frequency channel 
원 그리고 사용하는 주파수 채널의 이격에 따라 특성이 크 게 달라진다. 그림 $1(\mathrm{a})$ 는 간섭 분석 대표 모델로써 이를 통 해 실제적인 간섭의 영향을 분석한다.

FWS 망에서 간섭 유형은 주로 인접 채널 또는 동일 채널 간섭으로 나닌다 ${ }^{[1]}$. 동일 국소 인접 주파수 채널 간섭은 그 림 1(b)와 같이 동일 국소에서 이용하려는 주 신호와 인접한 간섭신호가 동시에 송수신되는 경우이다. 인터리브 방식의 경우 대다수가 이러한 형태의 채널 배치로 운용되고 있다. 즉 간섭을 일으키는 국소 $\mathrm{A}$ 에서 주 신호 $(\mathrm{fc})$ 와 간섭신호 $(\mathrm{fc}+\Delta)$ 가 동시에 송신되어 수신단인 국소 $\mathrm{B}$ 에는 2 개의 신 호가 전송 거리에 따른 손실 등으로 유사하게 수신되어 간 섭으로 작용하는 경우이다.

다른 경로의 돟일 주파수 채널 간섭은 그림 1(c)와 같다. 국소 $\mathrm{A}$ 에서 국소 $\mathrm{C}$ 로 송신하는 신호가 국소 $\mathrm{B}$ 까지 전송되 어 간섭을 주는 경우이다. 그림 1(c)와 같은 일직선인 경우 는 거의 없고 성형 또는 망사형으로 무선 중계 통신망이 구 성될 경우 많이 발생한다. 다른 경로의 인접 주파수 채널 간 섭은 그림 1 (d)와 같다. 국소 $\mathrm{A}$ 에서 국소 $\mathrm{B}$ 로 향하는 신호와 국소 $\mathrm{C}$ 에서 국소 $\mathrm{D}$ 로 향하는 신호가 인접 채널로 중첩되어 수신 국소(B 또는 $\mathrm{D})$ 에 간섭을 주는 경우이다. 이러한 간섭 유형은 가장 흔한 경우로 주 신호와 간섭 신호간의 채널 이 격도가 큰 영항을 미친다.

\section{2. 전송 채널 특성}

FWS의 간섭 성능을 분석하기 위해서 전송 채널의 특성 을 아는 것은 매우 중요하다. 이는 자유 공간 손실, 대기 흡 수 손실, 강우 감쇠 등의 요소로 나눌 수 있다 ${ }^{[1]}$.

FWS에서 송수신단 사이의 경로 감쇠의 주요 원인인 자 유 공간 손실은 식 (1)과 같다.

$$
L_{\text {free }}=\left(\frac{4 \pi d_{K m}}{\lambda}\right)^{2}=\left(\frac{4 \pi f_{c} d_{K m}}{c}\right)^{2}
$$

여기서, $d_{K m}$ 는 송수신단 사이의 거리, $f_{c}$ 는 송신 신호의 중심 주파수, $\lambda$ 는 $f_{d} d c$, 그리고 $c$ 는 광속이다.

그림 2 는 경로 거리에 따른 자유 공간 손실을 나타 낸 것

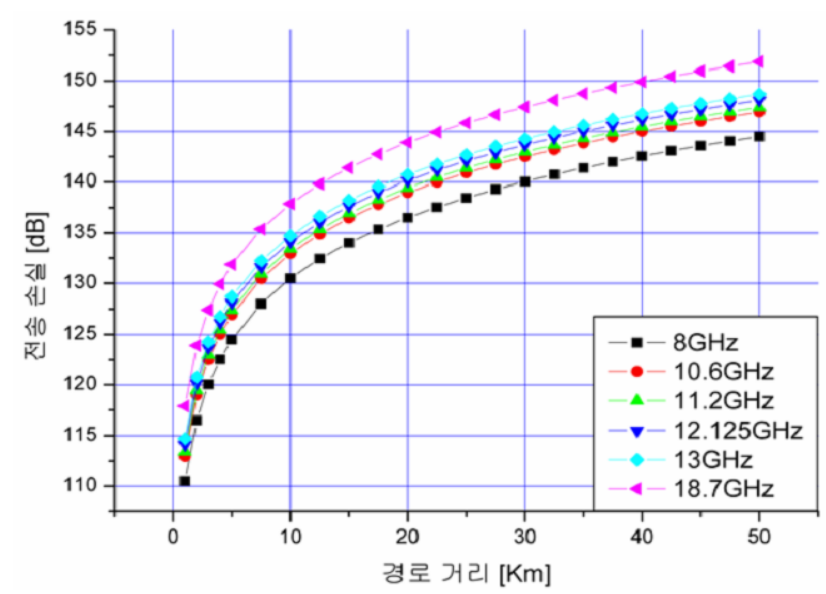

그림 2. 경로 거리에 따른 자유 공간 손실

Fig. 2. Free space loss vs. distance between FWS sites

이다. 이를 통해 경로 거리가 길어질수록, 전송 신호의 주파 수가 높아질수록 자유 공간 손실이 커짐을 알 수 있다. 대기 가스, 특히 산소, 수증기, 이산화탄소, 안개 등으로 인한 대 기 흡수 손실은 식 (2)와 같다.

$$
L_{\text {qas }}=\gamma \cdot d_{K m}=\left(\gamma_{0}+\gamma_{\omega}\right) \cdot d_{K m}
$$

여기서, $\gamma$ 는 $\gamma_{0}+\gamma_{\omega}$ 이며, $\gamma_{0}$ 는 건조한 공기 중의 감쇠량, $\gamma_{\omega}$ 는 수증기의 감쇠량을 각각 나타낸다.

그림 3은 경로 거리에 따른 대기 흡수 손실을 나타낸 것

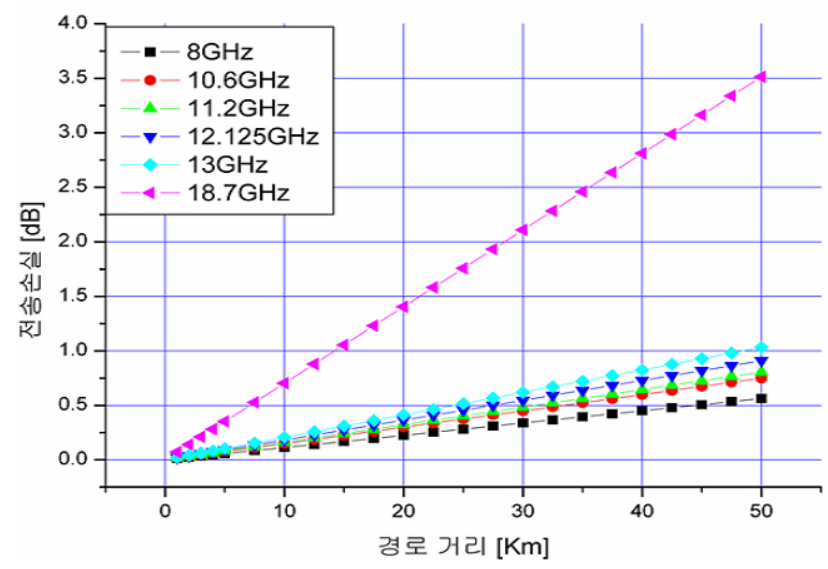

그림 3. 경로 거리에 따른 대기 흡수 손실

Fig. 3. Absorption loss vs. distance between FWS sites 
이다. 이를 통해 경로 거리가 길어질수록, 전송 신호의 주파 수가 높아질수록 대기 흡수 손실이 커짐을 알 수 있다.

마지막으로 강우의 전파 흡수, 산란 그리고 편파 교란으 로 인한 감쇠인 강우 감쇠는 식 (3)과 같다.

$$
\gamma_{r}(d B / K m)=k R^{\alpha}
$$

여기서, $R$ 은 시간당 강우의 강도이고, $k$ 와 $\alpha$ 는 주파수, 온도, 및 빗방울 크기의 통계적 분포 함수이다. 그림 4는 시 간당 강우 강도에 따른 강우 감쇠량을 나타낸다.

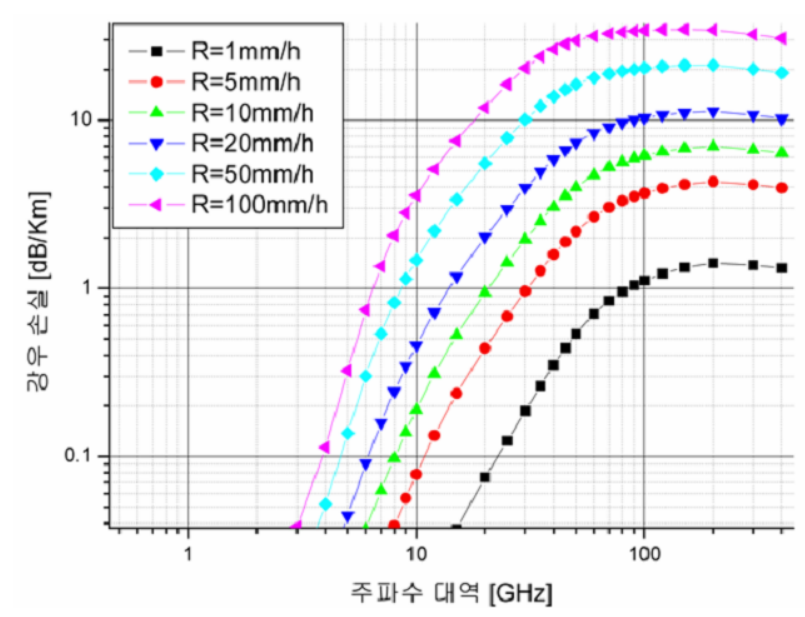

그림 4. 시간당 강우 강도 $R$ 에 따른 강우감쇠

Fig. 4. Rain loss vs. R per hour

\section{3. 허용 간섭 기준 도출}

동일 채널 간섭(CCI : Co-Channel Interference)은 이용 채 널 주파수 fc를 중심으로 요구되는 채널 대역폭 전체에 간섭 신호가 돟일하게 입력된다. 동일한 채널 대역폭에 간섭 전력 이 누적되므로, 간섭량은 캐리어 전력 양에 잡음 및 간섭이 합쳐진 양만큼 나눈 것으로 계산되며 채널에 직접적으로 영 향을 미친다.

인접 채널 간섭(ACI : Adjacent Channel Interference)은 이용 채널 주파수 $\mathrm{fc}$ 를 중심으로 요구하는 채널 대역폭과 일
정 간격으로 떨어져 있다. 간섭 신호로 입력되는 $\mathrm{fc}^{\prime}{ }^{\prime}$ 신호가 $\mathrm{fc}$ 중심 주파수의 채널 대역폭에 영향을 미친다. 겹쳐진 대 역폭만큼 간섭 전력이 누적되므로 인접한 정도에 따라 영향 도가 달라진다. 간섭 기준 산정을 위해서는 신호, 간섭, 잡음 등을 정의해야 한다. 캐리어 전력 $\mathrm{C}$, 잡음 전력 $\mathrm{N}$, 간섭량 I의 관계는 식 (4)와 같다 ${ }^{[12]}$.

$$
(C / N)_{t o t a l}=C /(N+I)
$$

식 (4)로부터 간섭 I가 없는 경우, $(\mathrm{C} / \mathrm{N})$ total은 $\mathrm{C} / \mathrm{N}$ 만이 존재하며, 간섭의 유입으로 $(\mathrm{CN})$ total이 열화된다. 이때 $\mathrm{C} / \mathrm{I}$ 는 $\mathrm{D} / \mathrm{U}(\mathrm{Desired} / \mathrm{Undesired}$ )와 간섭 감쇄 성분(IRF : Interference Reduction Factor)의 합으로 나타내어지며 돟일 채 널 간섭에서는 $\mathrm{IRF}=0$ 이 되어 결국 $\mathrm{D} / \mathrm{U}=\mathrm{C} / \mathrm{I}$ 가 된다. $\mathrm{IRF}$ 는 인접 채널의 간섭을 제거해 주는 필터의 특성이며, 채널 간 격, 채널 배치, 형태, 필터의 유형에 따라 다른 값을 지닌다. $\mathrm{IRF}$ 는 식 (5)와 같다 ${ }^{[1]}$.

$$
\operatorname{IRF}(\Delta f)=10 \log \left[\frac{\int_{0}^{\infty} G(f)|H(f)|^{2} d f}{\int_{0}^{\infty} G(f-\Delta f)|H(f)|^{2} d f}\right]
$$

여기서, $\mathrm{G}(\mathrm{f})$ 는 신호의 전력 밀도, $\mathrm{H}(\mathrm{f})$ 는 수신기 대역통 과 전달 함수이고, $\triangle f$ 는 원하는 신호와 간섭 사이의 주표수 간격을 나타내고, 인접 채널의 경우 $\mathrm{IRF}>0(\mathrm{~dB})$ 가 된다.

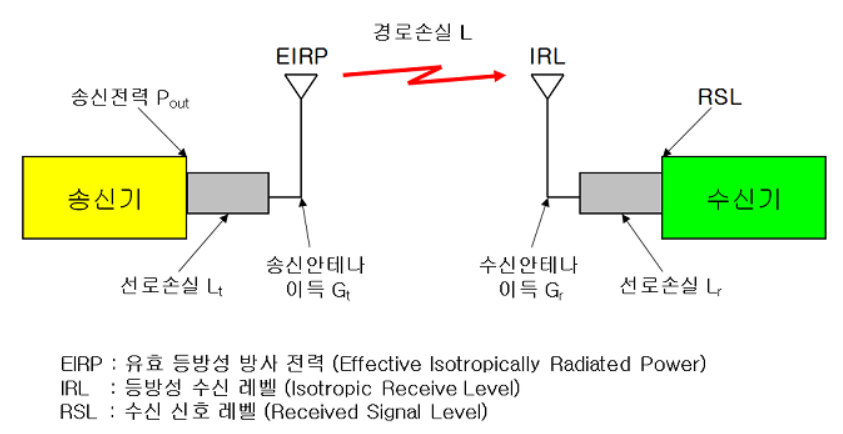

그림 5. 송 수신단 사이의 전력 관계

Fig. 5. Power budget between transmitter and receiver 
허용 간섭 기준 도출을 위해 필요한 구체적인 시스템 변 수들을 정의한다. 그림 5 는 송수신단 사이의 전력 관계를 나 타낸다. (C/N)total은 크게 $\mathrm{C} / \mathrm{N}$ 과 $\mathrm{C} / \mathrm{I}$ 로 크게 나눌 수 있으 며, 우선 $\mathrm{C} / \mathrm{N}$ 은 식(6)과 같이 나타낼 수 있다 ${ }^{[7]}$.

$$
C / N[d B]=E_{b} / N_{0}[d B]+10 \log \left(B / r_{b}\right)
$$

여기서, $\mathrm{B}$ 는 대역폭, $r_{b}$ 는 비트율을 나타내며, $E_{b} / N_{0}$ 는 식 (7)과 같다.

$$
E_{b} / N_{0}=R S L[d B W]-10 \log (b r)-P_{t h r}[d B]
$$

여기서, RSL(Received Signal Level)은 수신 신호 전력 레 벨을 나타내며, 식 (8) 식 (10)과 같이 정의된다 ${ }^{[13]}$.

$$
\begin{gathered}
E I R P[d B W]=P_{\text {out }}+G_{t}-L_{t} \\
\operatorname{IRL}] d B W]=E I R P[d B W]-\text { Pathloss }[d B] \\
R S L[d B W]=\operatorname{IRL}[d B W]+G_{r}-L_{r}
\end{gathered}
$$

또한 $P_{t h r}$ 은 열잡음을 나타내며, 식 (11)과 같이 나타낼 수 있다.

$$
\begin{aligned}
P_{t h r} & =k T B[W\rceil \\
& =-204+10 \log (B W)[d B W]
\end{aligned}
$$

여기서, $k$ 는 볼츠만 상수 $(-228 d B W \mathrm{sec} / K)$, T는 절대온 도를 나타낸다.

간섭의 유입으로 발생하는 C/I는 식 (12)와 같이 정의 할 수 있고, 이를 그림 6에 개념적으로 나타내었다.

$$
C / I=\left(P_{A}-P_{C}\right)+\left(G_{A}-G_{C}\right)-\left(L_{A B}-L_{C B}\right)+\left(M_{C}+M_{B}\right)(12)
$$

여기서, $\mathrm{P}$ 는 송신기 전력, $\mathrm{G}$ 는 안테나 이득, $\mathrm{M}$ 은 안테나 변별도, L은 경로 손실을 나타낸다.

식 (6) 및 식 (12)와 같이 산출된 양은 실제 시스템에서 허용 간섭 기준 도출을 위해 사용될 수 있으며, 이는 그림 7 과 같이 제안된 알고리즘에 의해 도출할 수 있다. 시스템 변

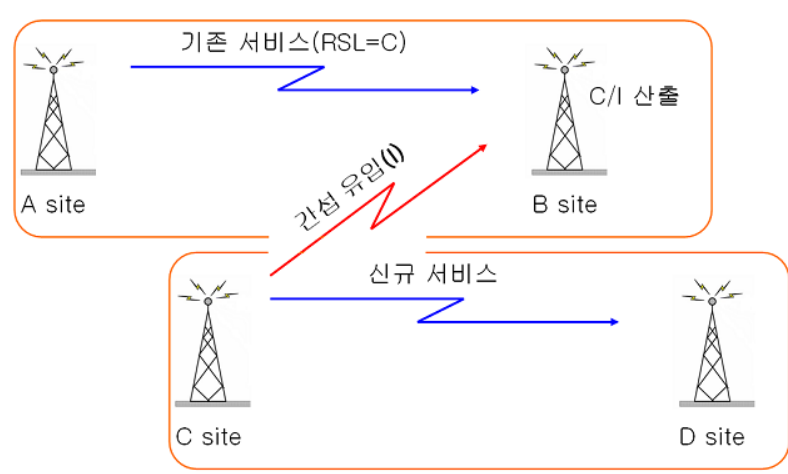

그림 6. $\mathrm{C} / \mathrm{l}$ 산출을 위한 시스템 구성

Fig. 6. System configuration to calculate $\mathrm{C} /$

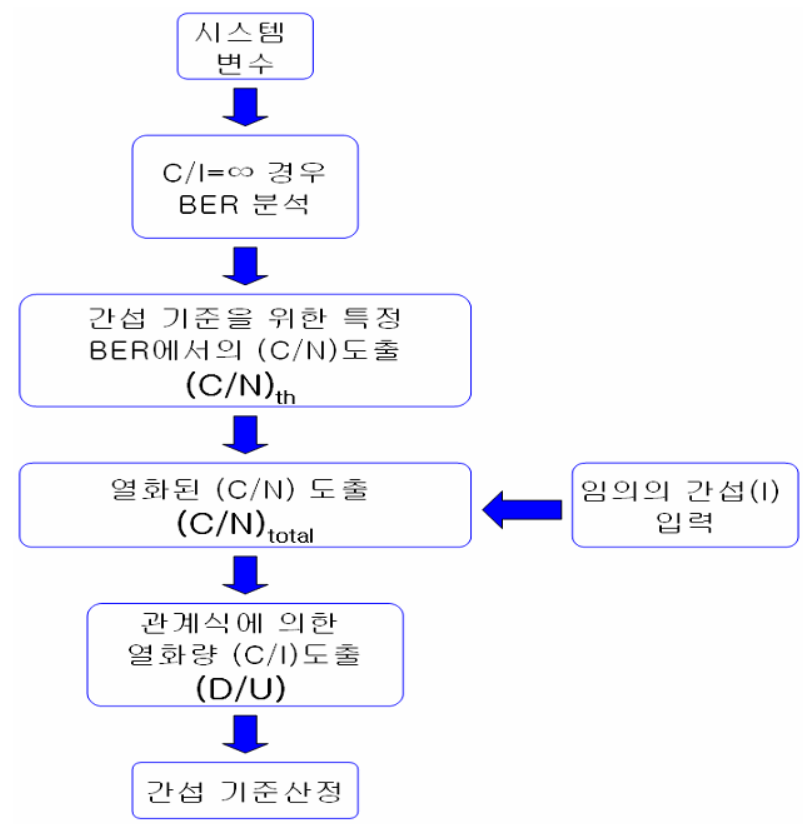

그림 7. 간섭기준 도출 방법론

Fig. 7. Proposed method to calculate interference criteria for FWS

수들을 통해 C/I가 무한대, 즉 간섭이 없는 일반적인 변조 방식 에 대한 $\mathrm{BER}$ 대 $\mathrm{CN}$ 을 도출한다. 이때 기존 시스템이 동작하 기 위한 목표 $\mathrm{BER}$ 을 정하고 이때의 $\mathrm{CN}$ 을 $(\mathrm{CN})$ th로 정한다. $(\mathrm{CN})$ th는 이 시스템이 돟작하기 위해 가져야할 최소한의 $\mathrm{C} / \mathrm{N}$ 값이 될 것이다. 그리고 임의의 간섭 전력을 유입한 후 열화된 $\mathrm{C} / \mathrm{N}$ 을 도출한다. 그리고 식 (13) 및 식 (14)을 통해 $\mathrm{C} / \mathrm{I}$ 값을 얻게 되고, 이를 통해 간섭 기준을 도출할 수 있다. 


$$
\begin{aligned}
& (C / N)_{t h}=10 \log \left(\left(10^{-\frac{\left(C / N_{\text {total }}\right.}{10}}+10^{-\frac{(C / D}{10}}\right)^{-1}\right) \\
& (C / D)=10 \log \left(\left(10^{-\frac{\left(C / N_{\text {th }}\right.}{10}}-10^{-\frac{\left(C / N_{\text {total }}\right.}{10}}\right)^{-1}\right)
\end{aligned}
$$

여기서, $(\mathrm{C} / \mathrm{N})$ th는 간섭이 없는 경우의 기준 $\mathrm{C} / \mathrm{N}$, (CAN)total은 간섭이 존재하는 경우의 열화된 $\mathrm{C} / \mathrm{N}, \mathrm{C} / \mathrm{I}$ 는 간 섭이 유입되는 경우의 원하는 신호와 간섭 신호의 비를 나 타낸다.

\section{III. 시뮬레이션 결과}

본 논문에서는 그림 7에서와 같이 제안된 간섭기준 도출 알고리즘을 이용하여 각 변조 방식별로 간섭이 유입되는 경 우 $\mathrm{C} /$ 변화를 통해 허용 간섭 기준을 도출 하였다. 변조 방식 은 디지털 방송 시스템에서 주로 사용되는 M진 QAM 방식 을 고려하였으며, 목표 BER은 $10^{-6}$ 과 $10^{-9}$ 으로 설정하었다. 그리고 인접 채널 방식의 경우 IRF는 20 으로 고려하였다.

그림 8은 동일 채널 간섭이 유입되는 경우 목표 BER이

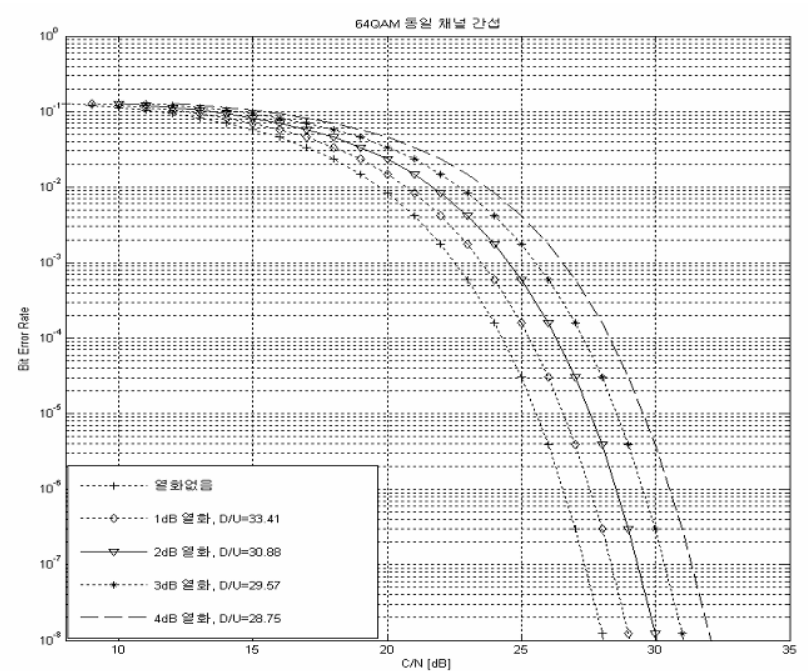

그림 8. 동일 채널 간섭이 있는 경우 64-QAM에서의 (C/N)total열화에 따른 $\mathrm{C} / \mathrm{D} / \mathrm{U})$

Fig. 8. $\mathrm{C} /$ due to $(\mathrm{C} / \mathrm{N})$ total degradation for 64 -QAM with same channel interference
$10^{-6}$ 일 때 $(\mathrm{C} / \mathrm{N})$ total 열화에 따른 $\mathrm{C} / \mathrm{I}(\mathrm{D} / \mathrm{U})$ 값을 분석하였 다. 변조 방식이 64-QAM인 경우 열화되는 값이 커질수록 $\mathrm{D} / \mathrm{U}$ 값이 작아짐을 알 수 있으며, 이는 열화되는 값이 커짐 에 따라 원하지 않는 신호 성분(U)이 증가함을 알 수 있다. 그림 9는 인접 채널 간섭이 유입 되는 경우 목표 BER $10^{-6}$

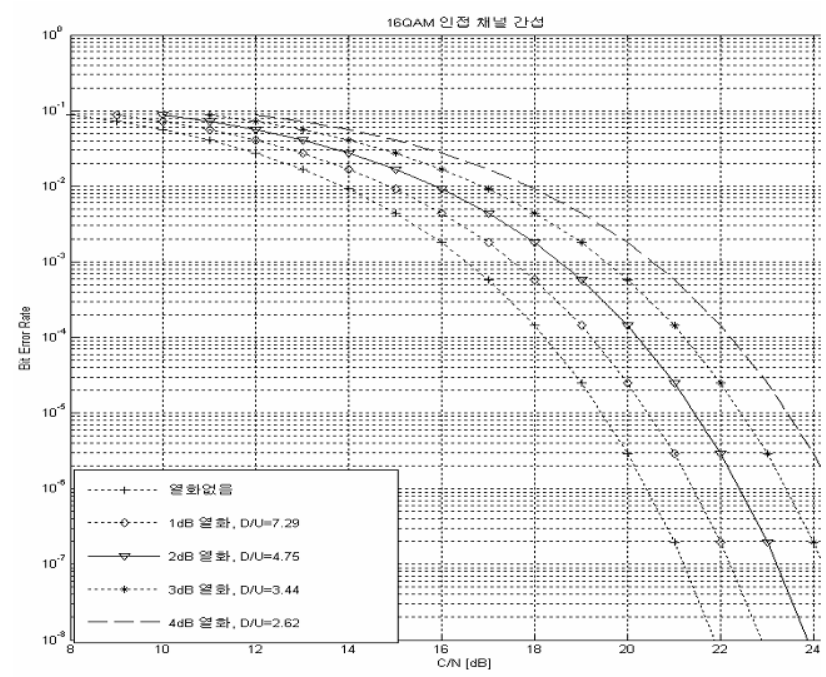

그림 9. 인접 채널 간섭이 있는 경우 16-QAM에서의 (C/N)total열화에 따른 $\mathrm{C} / \mathrm{D}(\mathrm{D} / \mathrm{U})$

Fig. 9. $\mathrm{C} /$ due to $(\mathrm{C} N)$ total degradation for 16-QAM with adjacent channel interference

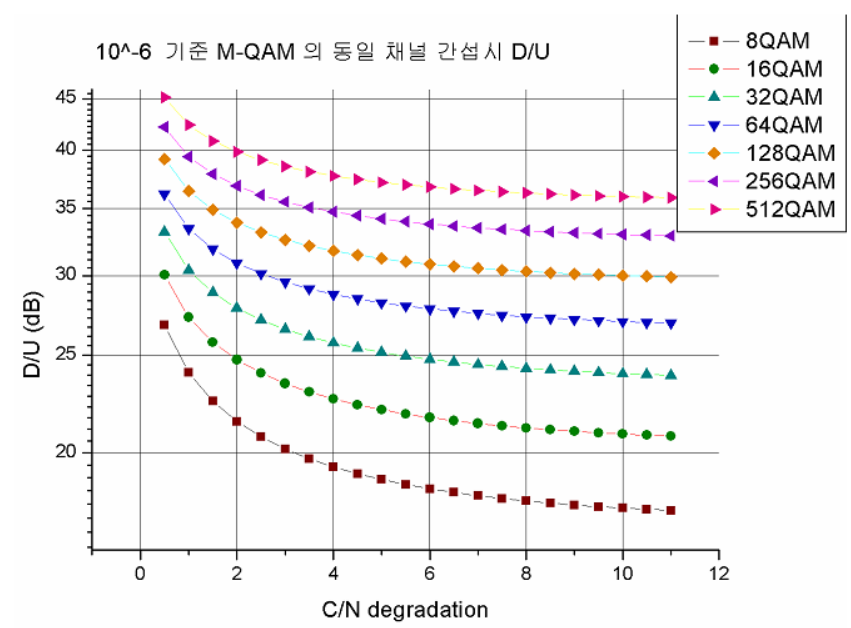

그림 10. 동일 채널 간섭이 있는 경우 목표 BER $10^{-6}$ 에서 (CN)total 열화에 따른 DN 특성

Fig. 10. DN due to (CN)total degradation for BER $10^{-6}$ with same channel interference 
에서 16-QAM 변조 방식에 대한 (CN)total 성능 열화 결과 이다.

그림 10 은 목표 $\mathrm{BER} 10^{-6}$ 에서 동일 채널 간섭시, 각 $\mathrm{CN}$ 열화에 대해 M진 QAM 변조 방식에 따른 $\mathrm{D} / \mathrm{U}$ 값을 나타낸 것이다. 그림 11 은 목표 $\mathrm{BER} 10^{-9}$ 에서 인접 채널 간섭시, 각 $\mathrm{CN}$ 열화에 대해 $\mathrm{M}$ 진 $\mathrm{QAM}$ 변조 방식에 따른 $\mathrm{D} / \mathrm{U}$ 값을 나타낸 것이다.

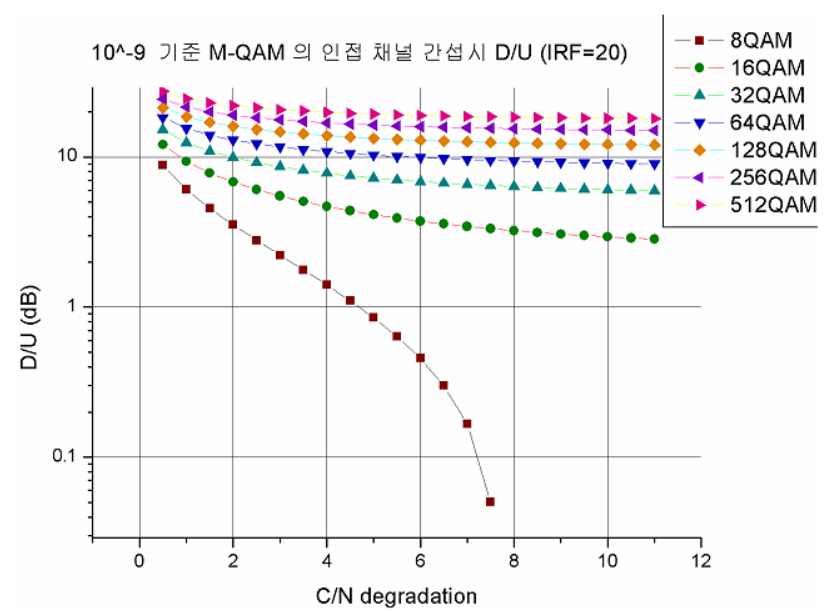

그림 11. 인접 채널 간섭이 있는 경우 목표 BER $10^{-9}$ 에서 (CN)total 열화에 따른 DN 특성

Fig. 11. DN due to $(\mathrm{C} N)$ total degradation for BER $10^{-9}$ with adjacent channel interference

그림 12 및 그림 13 은 동일 채널 간섭 및 인접 채널 간섭 의 경우 목표 BER에 대한 $\mathrm{D} / \mathrm{U}$ 값을 열화량에 대하여 비교 한 것이다. 역시 M진 QAM 방식에 대하여 D/U 성능을 보였 다. 512-QAM의 경우 8-QAM 방식에 비해 열화에 대하여 민감한 특성을 보인다.

산출된 결과는 실제 시스템에서 간섭의 기준으로 쓰일 수 있으며 신규 서비스의 도입의 유, 무를 판단할 중요한 근 거로 사용될 수 있다. 예를 들어, 표 1과 같은 시스템 특성을 가진 기존 시스템이 있는 경우, 본 논문에서 도출한 간섭 기 준을 통해 도입 여부를 결정할 수 있다. 표 1과 같이 이 시스 템은 외부의 간섭원으로 인해 $3 \mathrm{~dB}$ 이상 SINR이 열화되면 시스템이 정상적으로 동작할 수 없다.

그렇기 때문에 신규로 도입을 원하는 시스템은 이를 만족 시켜야 도입이 가능하다. 간섭이 작용할 경우, 허용 가능한

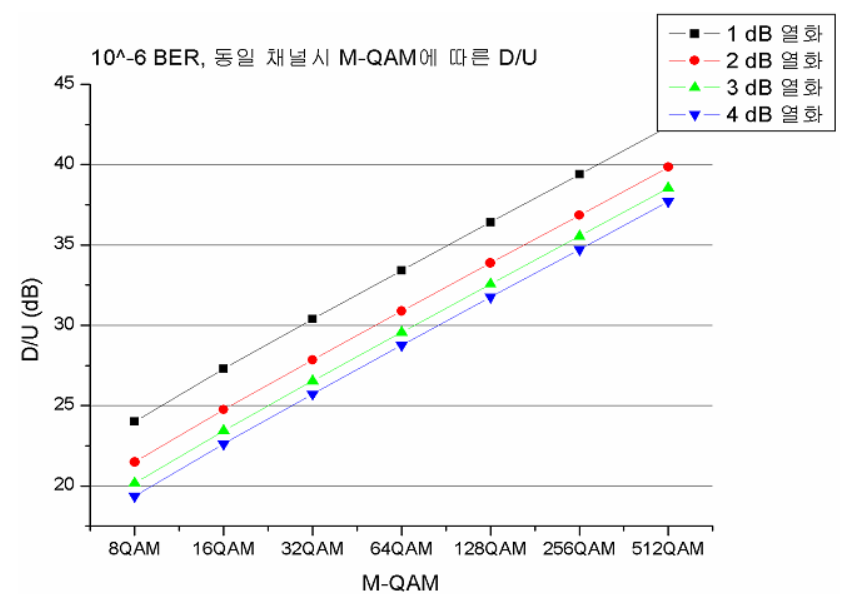

그림 12. 동일 채널 간섭이 있는 경우 목표 BER $10^{-6}$ 에서 M진 QAM변조에 따른 DN 특성

Fig. 12. DN comparison for M-ary with same channel interference (BER $10^{-6}$ )

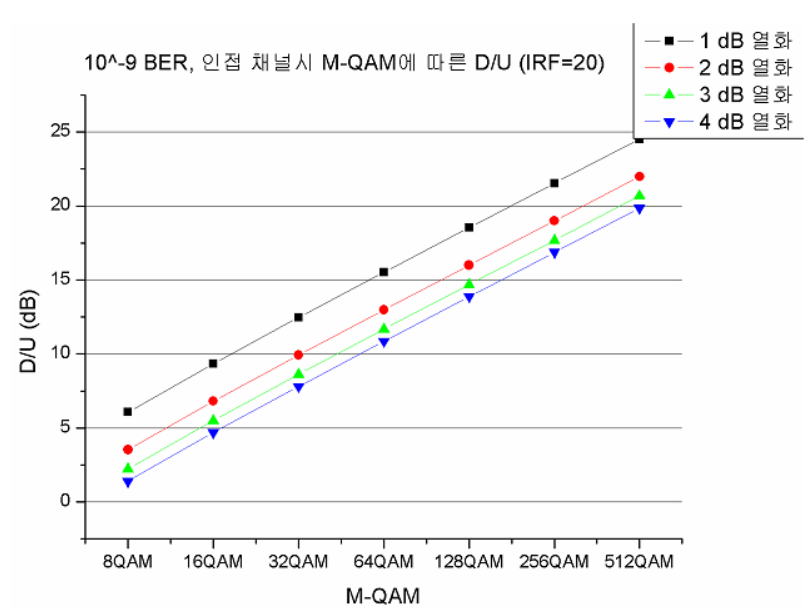

그림 13. 인접 채널 간섭이 있는 경우 목표 BER $10^{-9}$ 에서 M진 QAM변조에 따른 DN 특성

Fig. 13. DN comparison for $M$-ary with adjacent channel interference (BER $10^{-9}$ )

표 1. 기존 시스템 특성

Table 1. System characteristics of the current FWS

\begin{tabular}{c|c}
\hline 변조방식 & $64 \mathrm{QAM}$ \\
\hline 목표 $\mathrm{BER}$ & $10^{-6}$ \\
\hline $\mathrm{SINR}$ 허용 열화량 & $3 \mathrm{~dB}$ \\
\hline 간섭원이 동일채널인 경우 DN & $29.57 \mathrm{~dB}$ \\
\hline 간섭원이 인접채널(IRF=20)인 경우 $\mathrm{DN}$ & $9.57 \mathrm{~dB}$ \\
\hline
\end{tabular}


$\mathrm{D} / \mathrm{U}$ 값 역시 표 1에 주어져 있다. 이때, 각각 동일 채널 간섭과 인접 채널 간섭을 일으키는 신규 서비스 $\mathrm{A}$ 와 $\mathrm{B}$ 가 도입되기를 원한다면, 이들의 허용 여부를 판단하여야 하며, 이를 그림 14 에 정리하였다.

만약, 동일 채널 간섭을 일으키는 신규 서비스 $\mathrm{A}$ 가 기존 서비스에 미치는 간섭량이 많아서 $\mathrm{D} / \mathrm{U}$ 값이 $29.57 \mathrm{~dB}$ 미만 이 되면, SINR 허용 열화량이 $3 \mathrm{~dB}$ 이상이 되어 기존 시스 템은 정상적인 동작을 할 수 없게 된다. 이 경우, 신규 서비 스 $\mathrm{A}$ 는 도입이 불가능하다. 반면 인접 채널 간섭을 일으키 는 신규 서비스 $\mathrm{B}$ 가 기존 서비스에 미치는 간섭량이 적어서 $\mathrm{D} / \mathrm{U}$ 값이 $9.57 \mathrm{~dB}$ 이상이 되면, $\mathrm{SINR}$ 허용 열화량이 $3 \mathrm{~dB}$ 이하가 되게 되고, 기존 시스템은 정상적인 돟작을 할 수 있 게 되며, 신규 서비스 $\mathrm{B}$ 는 도입이 가능하다. 이와 같은 방식 으로 신규 서비스의 도입 여부를 제안한 허용 간섭 기준에 따라 판단할 수 있다.

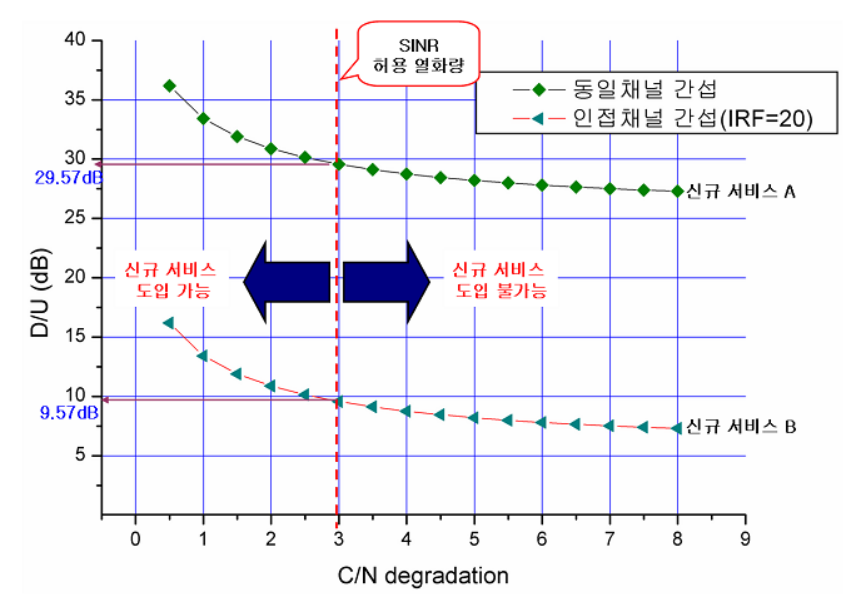

그림 14. 신규 서비스 도입 여부 판단

Fig. 14. An example of assessment to accept a new digital FWS

\section{IV. 결 론}

디지털 TV도입, $\mathrm{DMB}$ 등 각종 디지털 신규 서비스의 도 입으로 인해 주퐈수 대역에 대한 신규 요구가 발생하며, 기 존에 주퐈수 대역을 점유하고 있던 광대역 무선 업무와 신 규 도입되는 디지털 FWS간에 간섭이 발생하게 된다. 이를
효율적으로 다루기 위해 본 논문에서는 이들 간의 간섭 기 준을 산출하기 위한 새로운 도출 방법론을 제안하였다. 간섭 기준을 산정하기 위해 디지털 고정 통신망의 간섭원과 간섭 유형을 분석하었고, 전송 채널의 특성을 분석하였다. 제안한 방법을 디지털 시스템에서 많이 사용되는 M진 QAM 변조 방식에 적용함으로써 간섭 기준을 산정하였다. 이 간섭 기준 은 새로운 신규 디지털 서비스를 도입시 해당 서비스의 간 섭량 판단을 위한 기준으로써 사용될 수 있고 디지털 FWS 시스템의 성능 분석을 위한 도구로써 사용될 수 있을 것으 로 기대된다.

\section{참 고 문 헌}

[1] “디지털 $\mathrm{M} / \mathrm{W}$ 통신망의 동일 및 인접 채널 허응간섭 기준 연구", 한국 전자통신연구원, 2004년.

[2] “디지털 $\mathrm{M} / \mathrm{W}$ 통신망의 주파수 조정절차 연구”, 한국전자통신연구원, 2006년.

[3] ETSI TR 101 854, "Derivation of receiver interference parameters useful for planning fixed service point-to-point systems operating different equipment classes and/or capacities", 2005.

[4] Rec. ITU-R F.758-3, "Considerations in the development of criteria for sharing between the terrestrial fixed services and other services", 2004.

[5] UK, "Technical frequency assignment criteria", RA, June 2003.

[6] Rec. ITU-R P.530-10, "Propagation data and prediction methods required for the design of terrestrial line-of-sight systems", 2004.

[7] USA, Report \& tutorial : carrier-to-interference objectives, NSMA, Report WG 5.92.008, Jan. 1992.

[8] Australian Communications Authority, "Microwave fixed service frequency coordination(RALI, FX3)", 2003.

[9] Rec. ITU-R F.1094-1, "Maximum allowable error performance and availability degradations to digital radio-relay systems arising from interference from emissions and radiations from other source", 1995.

[10] W. D. Rummler, "A comparison of calculated and observed performance of digital radio in the presence of interference", IEEE Trans. on. Communications vol. COM-30, no. 7, pp. 1693-1700, July 1982 .

[11] Carlos, "Microwave radio link : from theory to design", Wiley-Interscience, 2003

[12] A. A. R. Townsend, 'Digital line-of-sight radio links: A handbook', Prentice Hall International(UK), 1988.

[13] Theodore S. Rappaport, 'Wireless communications principles and practice', Prentice Hall PTR, 2002.

[14] Roger L. Freeman, "Telecommunication system engineering 3rd", Wiley-Interscience, 1996.

[15] Vijay K. Bhargava, 'Digital communications by satellite: modulation multiple access and coding', Wiley-Interscience, 1981. 


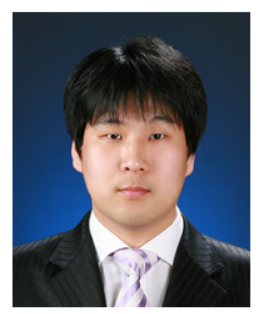

이 기 환

- 2007년 2월 : 경희대학교 전파공학과 졸업, 공학사

- 2007년 3월 현재 : 경희대학교 전자전파공학과, 석사과정

- 2009년 1월 : 삼성전자, 정보통신총괄 근무

- 주관심분야 : 전파통신시스템, Cognitive Radio, OFDM

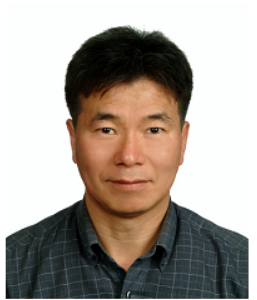

\section{이 주 환}

- 1988년 : 서강대학교 전자공학과 (공학사)

- 2000년 : 충남대학교 전파공학과 (공학석사)

- 1990년 현재 : 한국전자통신연구원 (책임연구원)

- 주관심분야 : 레이더 공유기술, 전파통신시스템 설계 및 간섭분석

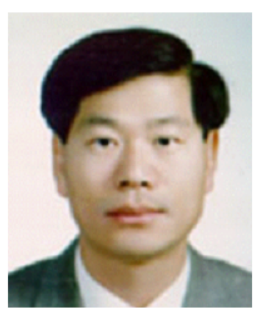

\section{서 경 환}

- 1991년 8월 : 한국과학기술원 공학박사 (초고주파 및 안테나 전공)

- 1983년 1월 1998년 10월 : 삼성전자 정보통신본부 수석연구원

- 1999년 3월 현재 : 강남대학교 전자공학과 교수

- 주관심분야 : 마이크로파 회로 설계, 무선전송시스템 설계 및 성능분석, RF모뎀 설계 및 구현, 무선채널 환경 및 간섭 분석

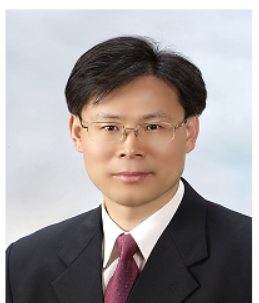

\section{송 주 빈}

He received B.S. and M.S. degree in 1987 and 1989 respectively and received Ph.D. degree in the Department of Electronic and Electrical Engineering from University College London (UCL), University of London, UK in 2001. From 1992 to 1997, he was senior researcher in the Electronics and Telecommunications Research Institute (ETRI). He was a research fellow in the Department of Electronic and Electrical Eng. at UCL in 2001. During 2002-2003, he was an assistant professor in the School of Information and Computer Engineering at Hanbat National University. He is currently an associate professor in the Department of Electronics and Radio Engineering, Kyung Hee University from 2003. He is a member of IEEE societies including communications, vehicular technologies, comsumer electronics, etc. He is a member of IEICE. His current research interests include broadband access networks, seamless access, high-speed telecommunications, mobile multi-hop networks, cognitive radio networks, and resource sharing technologies. 